\title{
Trains, Trade, and Transaction Costs: How Does Domestic Trade by Rail Affect Market Prices of Malawi Agricultural Commodities?
}

\section{Wouter Zant}

\begin{abstract}
We measure the impact of low-cost transport by rail in Malawi on the dispersion of agricultural commodity prices across markets by exploiting the quasi-experimental design of the nearly total collapse of domestic transport by rail in January 2003 due to the destruction of a railway bridge at Rivirivi, Balaka. Estimations are based on monthly market prices of four agricultural commodities (maize, groundnuts, rice, and beans) in 27 local markets for the period 1998-2006. Market pairs connected by rail when the railway line was operational are intervention observations. Railway transport services explain a 14 to 17 percent reduction in price dispersion across markets. Geographical reach of trade varies by crop, most likely related to storability and geographical spread of production. Perishability appears to increase impact, reflecting limited scope for arbitrage. Overall, impacts are remarkably similar in size across commodities.
\end{abstract}

JEL classification: D23, F14, N77, Q13, O18, O55

Keywords: domestic trade, crop prices, transaction costs, rail infrastructure, Malawi, sub-Sahara Africa

\section{Introduction}

High transport costs make trade between markets unprofitable and force farmers into subsistence farming. Conversely, low transport costs increase trade, lead to lower prices and lower price dispersion, and offer farmers incentives to commercialize. In the longer run, low transport costs may also increase supply response, improve allocative efficiency, accelerate technology adoption and innovation, and enhance economic growth. Sub-Saharan African countries, particularly landlocked ones, face high transport costs and suffer from high and volatile food prices and poorly functioning markets. Railway transport is a low-cost alternative to road transport and a feasible and useful complement to other modes of transport. Rail transport contributes to lower food prices through its impact on the operation of markets, increases welfare of households, and improves food security. Rail transport may also lead to a reduction of overall transport prices through rail-road competition.

Wouter Zant is associate professor at the Vrije Universiteit and fellow of the Tinbergen Institute, both Amsterdam, The Netherlands; his email address is wouter.zant@vu.nl. I am grateful to Hans Quené for assistance with compiling the data and to Jasper Dekkers for constructing maps. I also thank Peter Lanjouw, conference/seminar participants at Milan (ICAE2015), Oxford (CSAE2016), and Amsterdam (VU), and three anonymous referees of this journal for helpful comments. All remaining errors are my own. A supplementary online appendix for this article can be found at The World Bank Economic Review website. 
In this study, we investigate the hypothesis that, due to its low cost, railway transport services increase domestic trade in agricultural commodities. With increased trade flows of agricultural produce from surplus to deficit areas, prices will increase in surplus markets and decrease in deficit markets. As a result, dispersion of agricultural commodity prices across markets reduces and, consequently, the availability of low-cost rail transport services is associated with lower price dispersion across markets. The key empirical challenge in measuring impacts of infrastructure is to find an identification strategy that allows the separation of the impact of railway services from other factors. For the purpose of this research, we exploit a natural experiment, notably the disruption of a railway bridge in the heart of the Malawi railway network caused by a tropical storm in January 2003. The bridge collapse also caused a nearly total collapse of domestic freight by rail. In view of these developments, we assume that markets located along the rail line were connected with each other through rail transport services until January 2003 and lost this connection from January 2003 onward. Natural experiments in transport infrastructure are a rare event (see for example Jacoby and Minten 2008), and experimental designs in infrastructure are usually not feasible. ${ }^{1}$ Consequently, and apart from historical studies that exploit the rollout of the railway network as identification strategy (Donaldson 2010; Burgess and Donaldson 2012; Jedwab, Kerby, and Moradi 2014; Jedwab and Moradi 2016), impact studies on railway services are not common.

For the empirical estimations, we make use of monthly market prices for a few selected crops (maize, rice, groundnuts, and beans) in selected markets. These selected crops are grown in all Malawi districts, and the selected markets are evenly spread throughout Malawi. A number of these markets are located close to the rail line while others are remote from the rail line. The sample period stretches a number of years before and after the date of the bridge collapse. In the estimations, we explain (absolute) price dispersion of a number of food crops across markets. Price dispersion is assumed to be determined by market-specific factors (seasonality, trend, and fixed effects) and market-pair-specific factors (e.g., transport infrastructure). The estimation results support a 14 to 17 percent reduction in price dispersion across markets as a result of rail transport services. Geographical reach of trade varies by crop, most likely related to perishability, storability, crop value, and geographical spread of production. Perishability appears to increase impact, reflecting limited arbitrage opportunities.

The empirical literature on impacts of infrastructure is large. A substantial part is macro in nature, often taking a historical perspective, using rollout of infrastructure as identification, and deriving its theoretical underpinning from either new economic geography (including Davis and Weinstein) or trade theory (Ricardian comparative advantage, Heckscher-Ohlin, Eaton-Kortum). The impact of transport infrastructure research in the tradition of new economic geography and Davis and Weinstein centers around the question if the equilibrium distribution of economic activity across space is determined by locational fundamentals (geographical endowments) or economies of scale and scope due to concentration and clustering of activities and (past) investments (Jedwab and Moradi 2016; Jedwab, Kerby, and Moradi 2014; Redding and Sturm 2008; Bleakley and Lin 2012; Ahlfeldt et al. 2014). Jedwab and Moradi (2016) and Jedwab, Kerby, and Moradi (2014) exploit railroad construction respectively in Ghana and Kenya over the last century to show path dependence of economic activity and local increasing returns. Trade theory-based work looks at the impact of infrastructure on trade volumes, goods and labor markets, trade costs, and responsiveness to shocks (e.g., Michaels 2008; Feyrer 2009; Donaldson 2010; Burgess and Donaldson 2012; Atkin and Donaldson 2012; Allen and Atkin 2015). Donaldson (2010) exploits, in his extensive study on colonial Indian railways (1861-1930), the rollout of the railroad network and finds, on the basis of a general equilibrium trade model, that railroads reduce trade costs, reduce price dispersion between regions, increase trade volumes and welfare, and decrease income volatility. Burgess and Donaldson (2012) use the same identification strategy and find that railroads in India made prices and income less responsive to shocks. 
A different strand of the literature is directed toward the impact of infrastructure in contemporaneous developing countries and makes use of data with a shorter time dimension and a smaller space dimension, often micro-survey data (e.g., Yamauchi et al. 2011; Casaburi, Glennerster, and Suri 2013). Using (quality) improvements in road quality jointly with Indonesian household panel and village census data (1995-2007), Yamauchi et al. (2011) claim that the increase on household income growth and nonagricultural labor supply due to improved connectivity supports complementarity between education and quality of local roads. Casaburi, Glennerster, and Suri (2013) employ a genuine experimental design in rural road rehabilitation in Sierra Leone to estimate the impact on transport costs and market prices and test alternative models of price formation. They find price reductions in rice and cassava, larger for cassava and for locations remote from urban centers, and smaller in markets located in production areas. Part of the research on developing countries particularly considers the impact of transport and trading infrastructure on transaction costs, trade margins, commodity prices, household income, welfare, and supply response (Minten and Kyle 1999; Jacoby 2000; Jacoby and Minten 2008; Goyal 2010; Zant 2016). A key motivation for this research is the impact of high transaction costs on low-input, low-productivity, and low-growth agriculture, and thereby on welfare of rural households. Studying food prices in Zaire, both across regions and between products, Minten and Kyle (1999) show that transportation costs explain differences in food prices between producer regions and urban Kinshasa, and that road quality is the key determinant of transportation costs. Inspired by the difficulty of experimental designs in infrastructure, Jacoby (2000) and Jacoby and Minten (2008) take the reverse route and use the economic impact of transport costs on various economic variables and economic behavior (wages, value of agricultural land, household income, migration), in the absence of road infrastructure, in order to measure the potential gains of putting road infrastructure in place. Empirical application to Nepal data supports a substantial benefit to the poor which is, however, not large enough to reduce income equality (Jacoby 2000). Madagascar household data suggest large gains in income from improved infrastructure for remote households, but gains are small relative to the improved non-farm earning opportunities in town (Jacoby and Minten 2008). Focusing on marketing infrastructure in the soy market in Madhya Pradesh, Goyal (2010) finds increased soybean prices, decreased price dispersion, and increased area under soy cultivation, due to the introduction of a direct marketing channel by a major private company. Zant (2016) also finds a positive supply response of tobacco growers in Malawi due to improved market access caused by the introduction of a new auction floor.

In this study, we provide empirical evidence of the impact of rail transport services on dispersion of market prices of agricultural commodities. The estimation strategy is similar to the one used in Aker (2010), and the topic is closely related to literature that explains the impact of trade costs on prices (e.g., Minten and Kyle 1999). The remainder of the paper is organized as follows. In section 2, we briefly characterize the Malawi economy, present details on Malawi rail infrastructure and rail freight, and document the collapse of domestic rail freight since January 2003. In section 3, we explain the methodology underlying the empirical estimation and the identification strategy. In section 4 we present and discuss estimations, and in section 5 we give a summary and conclusion.

\section{The Malawi Economy, Transport by Rail, and Domestic Trade in Agricultural Commodities}

The Malawi Economy

Malawi is a small landlocked country in the south of Africa, measuring approximately $800 \mathrm{~km}$ from north to south and $150 \mathrm{~km}$ from east to west, in area size around 40 percent of the UK, bordering in the northwest with Zambia, in the northeast with Tanzania, and in the south with Mozambique. A large lake, Lake Malawi, part of the Great Rift Valley, stretches from north to south, along the east border of the country (see fig. 1). During the study period (1998-2006), the population increased from close to ten 
Figure 1. Malawi Railway Network and Selected Agricultural Markets

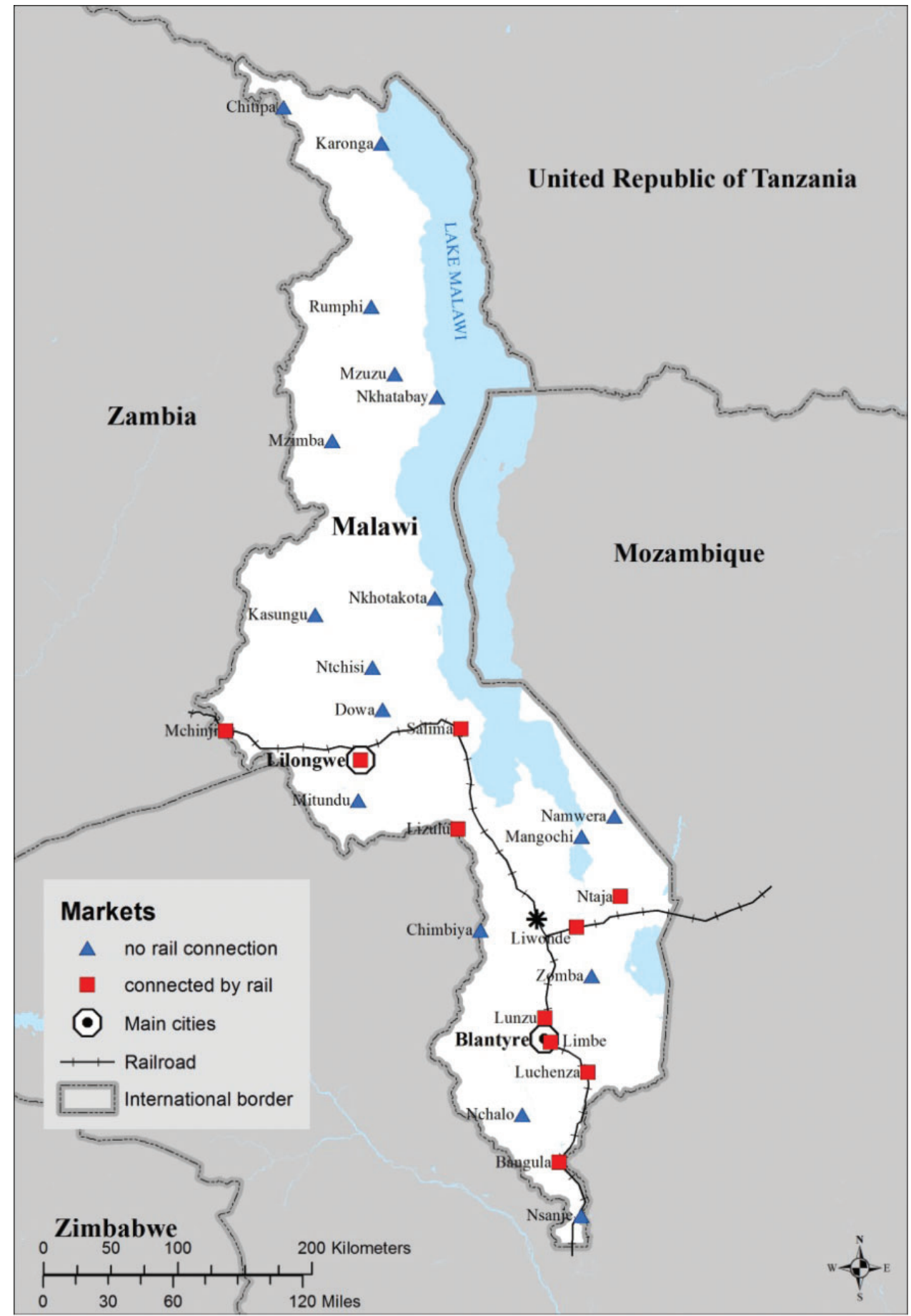

Source: SPINlab Vrije Universiteit Amsterdam.

Note: The asterisk on the map indicates the railway bridge at Rivirivi, Balaka. 
million to 13 million and is mostly rural: only a small fraction (11 to 15 percent) lives in the cities Lilongwe, Blantyre, Mzuzu, and Zomba. More than 80 percent of the Malawi population depends for food and income on subsistence farming. The incidence of poverty is high: more than 50 percent of the population in Malawi is poor (Integrated Household Survey 2005, National Statistical Office). Poverty is extremely high in remote rural districts (e.g., Chitipa 67.2 percent, Nsanje 76.0 percent, and Chikwawa 65.8 percent), and in the southern region poverty is at least ten percentage points higher relative to other regions. Malawi suffers from occasional food shortages due to drought and poor harvests (see Zant 2012, 2013). The key food crop is maize, followed by cassava, rice, groundnuts, and beans, all with considerably smaller shares. Nearly every city, town, or larger village has one or more markets for agricultural food crops on a regular basis, often daily or weekly. Both local farmers and traders operate on these markets.

Tobacco is by far the most important cash crop. Just like the other major cash crops, sugar and tea, tobacco cultivation dates back to the colonial period. Tobacco, however, has become nearly completely smallholder-based in the course of the 1990s (see Zant 2016), while tea and sugar production is (still) mainly on account of estates. The major export crops are marketed in a different way relative to food crops: through auctions in the case of tobacco and tea and through a large processing company (Llovo) in the case of sugar. Tobacco and sugar exports are also transported by rail.

\section{Malawi Markets for Agricultural Commodities: Production, Prices, Domestic Trade, and Demand}

In the empirical analyses, we consider prices of a few food crops, notably maize, rice, groundnuts, and beans. These food crops are important crops in the Malawi context, where maize takes an outstanding position, produced by nearly all farm households and accounting for 50 to 60 percent of the diet of most people in Malawi. Production of maize, rice, and beans is entirely consumed domestically, although in the case of bumper crops, small quantities are exported. Groundnuts are partly exported, but again, the bulk of production is consumed domestically. With the exception of rice, these crops are cultivated in all Malawi districts (see supplementary online appendix). ${ }^{2}$ Cultivation of groundnuts is concentrated in the central region and less common in the southern region, and pulses are concentrated in the southern region and less common in the north and central region.

Seasonality in production combined with a constant demand translates into strong seasonality in prices: prices tend to be low in the months after harvesting (April to June), and subsequently increase continuously to reach high levels just before the next harvest is available. Differences between highs and lows are often larger than 100 percent (see supplementary online appendix), and this has major implications for food security (see, for example, Kaminski, Christiaensen, and Gilbert 2016). Since price differences across markets are a key driver of trade in agricultural commodities, variations in price seasonality across markets are also likely to trigger trade. Seasonality in prices is more pronounced in urban areas, due to higher income, larger population, and lower local supply. Price seasonality is, on average, largest in maize, smallest in rice, and groundnuts and beans are in between. ${ }^{3}$ Maize is also an exception in terms of (relative) value: rice, beans, and groundnuts are high-value crops with prices of, on average, four to five times the price of maize (but with distinct variations by crop, by year, and by market; see supplementary online appendix). Trade in high-value crops is more attractive due to proportionately lower trade costs.

The predominantly small-scale domestic trading business in food crops is undertaken by farmers; small, medium, and large traders; wholesalers; maize-processing firms; and the Agricultural Development and Marketing Corporation (ADMARC). The dispersion of the size distribution of trader businesses and the prevalence of many small-scale businesses suggest constant returns to scale in trade

2 A supplementary online appendix for this article can be found at The World Bank Economic Review website.

3 We calculate seasonality in prices by dividing monthly prices with average price. The average price is a centered 12 month average with a moving window. The resulting number that measures the extent to which monthly prices diverge from the season average is dimensionless and automatically takes account of price changes over time. 
(Fafchamps, Gabre-Madhin, and Minten 2005). Most "district to district" trade of maize runs from farmers to small and medium traders and occasionally to larger traders and wholesalers. Around 75 percent of all traders buy directly from farmers and sell as a retailer (Fafchamps, Gabre-Madhin, and Minten 2005). Trading channels vary by location, but the bulk of maize trade is in the hands of the private sector. Survey data indicate that average distance between purchase location and sale location of maize transactions is around $55 \mathrm{~km}$, with a maximum of $200 \mathrm{~km}$ (Fafchamps, Gabre-Madhin, and Minten 2005).

Although transport of agricultural produce by rail is a cheap transport alternative, transport by road is the dominant mode of transport of trade in agricultural products in Malawi. For a variety of reasons, however, domestic transport costs of transport by truck are very high: the main causes include poor (secondary) roads, high petrol prices, inefficient small loads, no backloads, no scale economies, credit constraints, and limited competition (see Lall, Wang, and Munthali 2009; Zant 2013). The trunk road network (see appendix A1, fig. A1.1) connecting cities and district towns functions reasonably well, but the lack of good secondary roads leaves many locations underserved. Cheap transport services in Malawi potentially create large welfare gains and enhance the scope for economic growth. If fully operational, the (extended) railway system in Malawi is therefore an interesting complement to the currently dominant mode of transport.

\section{Railway Infrastructure, Operations, and Transport Costs}

The Malawi rail network consists of a single rail line with a total length within Malawi of $797 \mathrm{~km}$, running from Zambia in the west (where it runs $25 \mathrm{~km}$ into Zambian territory to Chipata), to the east via Lilongwe and Salima, and next to the south where-in the district of Balaka-the line splits into a line farther south to Blantyre and Beira in Mozambique, and a line to the east to Nacala in Mozambique (see fig. 1). Historically, the line is operated by a government-owned railway company, Malawi Railways. However, on December 1, 1999, a 20-year concession for the operation of the network and supply railway transport services has been awarded to Central East African Railways (CEAR). This concession, an integrated part of a larger concession (with the US-based Railroad Development Corporation, as main concessionary), known as the Nacala corridor, further consists of the port of Nacala in Mozambique, a railway line that runs from Nacala to the Malawi border, and a $26 \mathrm{~km}$ railway line from Mchinji at the western border of Malawi to Chipata in Zambia. The Mozambique parts are owned by the parastatal Mozambique railway company Caminhos de Ferro de Moçambique (CFM) and operated by the joint venture Corredor de Desenvolvimento do Norte $(\mathrm{CDN}){ }^{4}$ Investment in railway lines in the region is driven, in the first place, by the exploration of quarrying and mining companies. ${ }^{5}$

The rail network has not been fully operational in the past, among other things because of the civil war in Mozambique (1977-1992), destruction by floods, and poor maintenance. Lall, Wang, and Munthali (2009) characterize the role of railroads in Malawi as follows: "rail has historically been the main mode for international freight transport, connecting Malawi with its southern neighbors of Mozambique, Zimbabwe, and South Africa. However, the civil war in Mozambique from the midseventies cut off the two main rail arteries-the Nacala and Beira-Sena lines. With the Nacala line being mined and the destruction of the main bridge across the Zambezi River on the Beira-Sena lines, the importance of rail in Malawi's international freight movements has declined.”

However, the (potential) importance of the railway for domestic trade in the Malawi economy is acknowledged in policy documents: "Rail transportation is also an important mode of transport for rural farmers who usually use the train to move their farm produce to main markets in the cities or trading centers. Such commodities include tomatoes, pigeon peas and other vegetables. In 2006, CEAR recorded

4 See Knapp and Posner 2004. Since privatization in 1999 and up to the time of writing, several other private-sector parties have participated in CDN.

5 A search on Sub-Saharan African railways in the archives of news sources (All Africa [www.allafrica.com], International Railway Journal, Railway Gazette International) generates nearly exclusively articles related to mining. 
approximately 480,000 passengers moved, largely smallholder farmers. Since 2000, CEAR moved over 250,000 tons of local products to main markets locally but has been experiencing reduced usage by the locals to transport their commodities using rail transportation" (Millennium Challenge Corporation 2011).

What about unit transport costs by rail relative to unit transport costs by road? World Bank (2006) compares local road transport costs in 2003 with average per ton-kilometer tariffs for a number of Sub-Saharan African corridors and rail operators. Unit road transport costs are calculated to be a factor 1.4 to 3.1 higher. ${ }^{6}$ Donaldson (2010) claims that road transport in India is 4.5 times more costly relative to rail transport. Various studies further stress the role of rail transport in keeping road tariffs in check, and this is particularly relevant to Malawi, which has notoriously high road transport costs (see Lall, Wang, and Munthali 2009). In summary, rail transport is clearly cheap relative to road transport and potentially leads to reductions in unit road transport costs. Moreover, in many Sub-Saharan African countries, road infrastructure is supplied at less than full recovery cost, creating a road-rail competition imbalance (World Bank 2006; Teravaninthorn and Raballand 2008).

Transport by Rail and the January 2003 Collapse of Domestic Freight by Rail

What can we learn from data on Malawi transport by rail? Figure 2 shows Malawi transport by rail (freight in ton-km) in the period 1997-2007. Despite fluctuations, the figure reveals a clear structural

Figure 2. All Trade by Rail (Monthly)

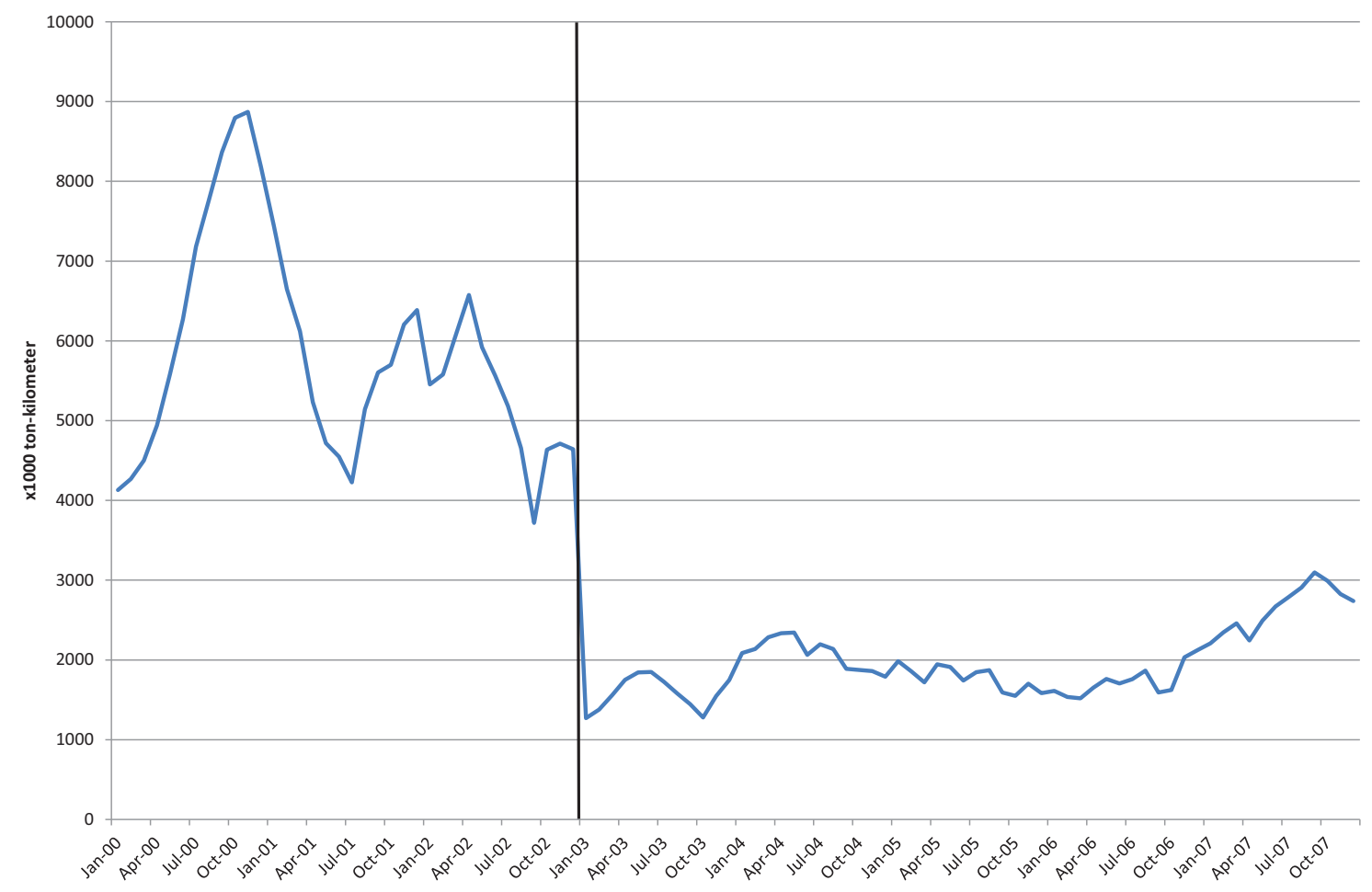

Source: Authors' calculations based on Central East African Railways data (CEAR).

6 Average tariffs for, respectively, road and rail transport services in US\$ per ton-kilometer are: 7.9, 5.3 (Senegal-Mali, Transrail), 7.9, 5.5 (Cote d'Ivoire-Burkina/Mali, Sitarail), 11.2, 6.3 (Cameroon-Chad, Camrail), 10.0, 5.5 (Mozambique, CCFB/CFM), and 13.5, 4.3 (Tanzania-Great Lakes, TRC), with in parentheses respectively corridor and rail operator (World Bank 2006). 
break in trade volume starting in January 2003 when a large decrease of freight occurred. The large decrease coincides with a nearly total collapse of domestic trade and, somewhat less pronounced, by a drop in passenger transport (see appendix A1 figs. A1.2 and A1.3).

The collapse in rail transport expressed in the figures is for a large part ${ }^{7}$ on account of the disruption of a bridge at Rivirivi in Balaka district, located in the center of the rail network (see fig. 1), in its turn caused by a tropical storm named Delfina. Delfina started on December 30, 2002, at the northwest coast of Madagascar, intensified while moving westward before hitting northeast Mozambique on December 31, and weakened while moving inland by January 1, 2003, into Mozambique and Malawi. By January 9, Delfina had died out. The major damage of the storm was done in Mozambique. In Malawi, the storm's remnants caused flooding in several districts, although not widespread. Delfina damaged roads, and, most importantly for our study, destroyed the railway bridge at Rivirivi in Balaka district. The storm further destroyed about 3,600 houses, and around 30,000 people were forced to leave their homes; floods affected 57,000 properties, damaging 23,500 ha of agricultural land. ${ }^{8}$ Delfina killed eight people in Malawi, prompting President Muluzi to declare the country a disaster area on January 11 (Wikipedia 2017).

The decrease in freight was, however, not uniform across types of freight. Export and import freight by rail has shown a different development relative to domestic freight by rail. Malawi exports tobacco, sugar, and beans, and imports fuel, fertilizer, and food aid, all key products for the Malawi economy. Part of imports and exports are transported by rail because of low costs for exporters and importers and because of stable turnover for the railway company. Also, food aid is claimed to be efficiently and cost-effectively transported by rail (see the archive of All Africa at allafrica.com). CEAR annual freight data (tonkilometer moved) show large increases in exports in 1999 and 2000, possibly associated with the privatization of railway services and enhanced by the 1998 devaluation of the Malawi kwacha (see supplementary online appendix). Export and import freight were also much less affected by the 2003 bridge collapse, although tobacco exports have come to a complete standstill. ${ }^{9}$ The average share of local freight (vis-à-vis international trade) has dropped from around 50 percent before 2003 to around 10 percent from 2003 onward (see supplementary online appendix). The data suggest that CEAR has prioritized more profitable imports and exports rather than local freight and passenger services. ${ }^{10}$

Repair of the bridge in the period after the storm and restarting railway operations took quite a while; disagreements between CEAR and the Malawi government as to who should pay to rebuild the bridge caused substantial delay in making the railway line operational again. In May 2005, close to two and a half years later, and with support from USAID and the UK DfID, the Rivirivi railway bridge was reconstructed, and rail transport operations were resumed. ${ }^{11}$

The dramatic sequence of events has created an interesting opportunity to measure the impact of rail transport services on markets. For a rigorous impact measurement, one ideally needs records of bilateral

7 The drop also coincides with the closure of a quarry at Changalume ( $86 \mathrm{~km}$ north of Blantyre) in 2002, which used to supply clinker to a Blantyre cement plant. Unfortunately, we are unable to construct local freight data excluding freight of clinker. The closure is unlikely to affect market prices of agricultural commodities.

8 Despite the casualties and damage, we were unable, using annual aggregate data sourced from the Ministry of Agriculture and Food Security, to find an adverse impact on agricultural production of the affected districts.

9 Note that the bulk of tobacco for export is sourced from central and northern Malawi (see Zant 2016).

10 The bias toward international freight is apparent from the operational strategy of CEAR reported in various newspapers. Alternatively, domestic passenger services were suspended for periods and for segments in the network partly due to disagreements with the Malawi government about the extent of subsidy for these services (see Mvinyo 2006).

11 Personal communication of the author with CEAR staff. In January 2005, Railway Gazette International reported: "Work to repair damage to the Rivirivi Bridge caused by Cyclone Delfina in January 2003 is nearing completion, and CEAR hopes to restore train services shortly." (See “Malawi.” 2005. Railway Gazette International, 161 (1): 12-14. Accessed June 11, 2017. http://www.railwaygazette.com/news/.) 
trade flows by rail, including prices by market and traded quantities of agricultural products by source and destination both before and after the disaster had taken place. Unfortunately, such data on trade by rail are not available. As a matter of fact, we also do not know to what extent trade in agricultural commodities by rail takes place in the form of passenger trade-smallholder farmers and traders traveling by train to nearby town and city markets in order to sell their produce-or in the form of formal freight. ${ }^{12}$ What is available is data on market prices of agricultural commodities for a large number of markets in Malawi. Hence, in this study, we aim to measure the impact of railway services on market prices of these agricultural products.

\section{Measuring the Impact of Railway Services on Dispersion of Market Prices}

\section{Data}

For the empirical work, we use monthly retail market prices of agricultural commodities taken from the Agro-Economic Survey of the Ministry of Agriculture and Food Security. We have these data for a long period (from 1991/92 to 2008/09), for a large number of markets (around 70), and for a large number of agricultural commodities and livestock products (around 20). However, for the purpose of this study, we use a limited subset: we use price data of only four crops (maize, rice, groundnut, and bean prices), for 27 markets, and for the period from January 1997 to December 2007. We have selected crops that are widely produced and consumed, markets that have the most complete price data, ${ }^{13}$ and a sample period that covers a distinct number of years before and after the bridge collapse. Even the selected price data are not complete, and, more troublesome, especially in the period of key interest to our research (around January 2003), a substantial drop in the completeness of the data occurs, most likely due to the food crises at the time (see supplementary online appendix). ${ }^{14}$

All distances used in the empirical part are distances as the crow flies, calculated using standard Great Circle Distances, and based on latitude-longitude coordinates of locations (markets, railway stations). We are aware that distance measured as the crow flies differs from road distance and that road distance is the relevant concept for transport costs. However, since we do not exactly know the (changes in) road distance at the time, we rather avoid the likely but uncertain error and prefer the clear and transparent approximation of distance.

In the estimations we include the following three covariates $\left(X_{j k, t}\right)$ : rainfall, population density, and per capita (gross) income. Rainfall is an annual index of crop season rainfall in mm. normalized with the long-run average crop season rainfall in mm. Rainfall is recorded in around 30 weather stations and attributed to markets on the basis of proximity. We expect that above-average rainfall increases crop production and the availability of agricultural commodities after harvest, and increased supply will reduce prices. Hence, we expect current crop season rainfall to have a negative impact on the following year price. In terms of price dispersion, we expect that a large difference in rainfall between locations increases price dispersion. Rainfall data are from Department of Climate Change and Meteorological Services, Ministry of Natural Resources, Energy and Environment in Blantyre.

12 Fafchamps, Gabre-Madhin, and Minten (2005) report that, in their 2000 Malawi trader survey, none of the traders made use of transport by train. However, the impact that we are after also concerns farmers (rather than traders) who take up trading activities and sell their output in a nearby town to fetch a higher price rather than selling at the farm gate or the local market. Evidence on Ugandan coffee farmers suggests that such activities are not uncommon (see Fafchamps and Vargas-Hill 2005). A nearby railway station makes this proposition even more profitable for a farmer.

13 In order to maintain the informational content of prices, we have refrained from imputing values for missings.

14 Malawi and Malawi agriculture suffered from floods and inundation in 2001 and from droughts in 2002, leading to a prolonged food crisis. Under these circumstances, one may expect that markets do not operate normally and are characterized by a lack of transactions. Therefore, we have carefully observed to have a sufficient number of available data for estimation, especially in the period from January 2003 onward. 
Population density is the number of people per square kilometer, by Extension Planning Area (EPA) or district/Rural Development Project (RDP). Population size varies between districts but moves only gradually over time. Higher population densities are associated with more trade and more efficient trade (see Fafchamps, Gabre-Madhin, and Minten 2005). Hence, we expect price dispersion between locations to decrease the larger the population density in both locations. Population data are from the National Statistical Office in Zomba.

Per capita income is an annual district variable, constructed as the sum of agricultural income and imputed urban income. Gross income from agriculture is calculated by multiplying agricultural production with average retail market prices, both by crop season and district and by summing over crops and livestock products. ${ }^{15}$ All prices are deflated with the consumer price index for rural areas (source: National Statistical Office, Zomba, Malawi). We then exploit data on rural and urban population by district: we first calculate the per capita agricultural income by using rural population data by district. Next, we assume that the highest per capita agricultural income in the region is related to per capita income of the urban population: we impute $n$ times the region highest per capita agricultural income to the urban population, where $n$ reflects the productivity differences between urban and rural workers. ${ }^{16,17}$ Per capita income accounts for demand, and we expect that a higher per capita income increases demand and pushes up prices of agricultural commodities. Large differences in income between locations will, ceteris paribus, increase price dispersion. All covariates are expressed in terms of the natural logarithm of the absolute value of the difference between markets $\left(\ln \left|x_{k}-x_{j}\right|\right)$.

\section{Theoretical Considerations}

Costs of railway transport are relatively low compared to transport costs by road, which is the standard mode of transport in Malawi. Farmers and traders in Malawi, based in areas near a railway station, potentially benefit from these cheap transport services. The lower transport costs enhance trade in agricultural commodities markets along the railway line, increasing flows of goods from surplus to deficit areas and thereby raising low prices in surplus areas and reducing high prices in deficit areas. Hence, availability of railway transport services should reduce price dispersion across markets along the railway line. The key mechanism that drives this process is standard profit-maximizing producer behavior with transaction costs.

\section{Empirical Specification}

For estimating impact, we apply a panel fixed effects strategy and use the following regression model:

$$
\begin{aligned}
Y_{j k, t}= & \beta_{0}+\sum_{i} \beta_{1 i} Y_{j k, t-i}+\beta_{2} \text { connected by rail }{ }_{j k, t}+\sum_{n} \beta_{3 n} X_{n, j k, t} \\
& +\sum_{l} \beta_{4 l}\left(\text { time. } \omega_{l}\right)+\sum_{s l} \beta_{5 s l}\left(\text { season }_{s} . \omega_{l}\right)+\omega_{l}+\phi_{t}+\eta_{j k}+\zeta_{j k, t},
\end{aligned}
$$

15 We distinguish the crops maize (local, composite, and hybrid), rice, millet, sorghum, cassava, sweet potatoes, groundnuts, pulses, cotton, tobacco, tea, and sugar, and the livestock products steak, pork, mutton, and goat meat.

16 Urban population only refers to a fraction of the population of the districts of Lilongwe, Blantyre, Zomba, and Mzimba. We use $n=1.5$; however, a range of values varying between 1 and 3 did not fundamentally change the estimation results. We cannot calibrate the value of $n$ with GDP data because of the subsistence character of the Malawi economy: home-consumed production is included in our per capita income concept, but it does not show up in per capita GDP.

17 There are a multitude of explicit and implicit assumptions in this per capita income calculation with many arbitrary elements, which many researchers will label as "heroic." Nevertheless, the constructed data should give a sensible order of magnitude approximation for per capita income. 
where $Y_{j k, t}$ is the dispersion of prices across markets $j$ and $k$, at time $t$; connected by rail is a variable with a value $\ln$ (distance) if both markets are less than $20 \mathrm{~km}$ away from a railway station when the railway is operational, and zero otherwise, where distance measures the distance in kilometers between the markets; $X_{n, k, t}$ is a vector of $n$ market-pair variables at time $t$, affecting the dispersion of prices across markets $j$ and $k$; time is a time trend; season is seasonal dummy; $\omega_{l}, \phi_{t}$, and $\eta_{j k}$ are market, time, and market-pair fixed effects; and $\zeta_{j k, t}$ is a cluster robust error term.

There are several ways to measure dispersion of prices across markets $\left(Y_{j k, t}\right)$, like, for example, the coefficient of variation or the maximum minus the minimum. We follow Aker (2010) and use (the natural logarithm of) the absolute price difference across markets $\left(\ln \left|\mathrm{p}_{j}-\mathrm{p}_{\mathrm{k}}\right|\right)$. In the estimated specification we have included the lagged dependent variable as an explanatory variable in order to filter out lagged responses. The vector of $X_{j k, t}$ variables are determinants of price dispersion between markets $j$ and $k$, associated with either transaction costs (like transport costs, gasoline prices, and economies of scale), or local supply and demand balances. In the estimated equations we further include time trends and seasonality by market. ${ }^{18}$ Crop and market-specific seasonality in prices is supported by the data (see supplementary online appendix). Monthly fixed effects are included to control for countrywide variations in agricultural production and demand over the years (for example, caused by bumper crops and droughts).

\section{Identification Strategy}

The exogenous collapse of railway transport services due to the disruption of the railway bridge at Rivirivi, documented in the previous section, creates a quasi-experimental design that offers an opportunity to identify the impact of railway services on the dispersion of agricultural commodity prices. The regression equation represents a panel fixed effects model with markets connected by rail when the railway was operational, as intervention observations. The coefficient of interest in the regression equation is $\beta_{2}$ : this coefficient reflects the impact of the availability of railway transport services on the dispersion of agricultural commodity prices. We expect price dispersion to be lower in locations that have access to railway transport services. Hence, we expect $\beta_{2}$ to be negative.

\section{Intervention Locations}

In this study, interventions are the market pairs that are connected with each other by rail when the railway is operational. Moreover, we have assumed that, after the bridge collapse, all segments of the network were affected, and, hence, all market pairs formerly connected were no more connected after the bridge collapse. This assumption is supported by communication with CEAR staff and freight data on domestic trade. We assume that markets potentially have access to rail transport if these markets are less than $20 \mathrm{~km}$ away from the nearest railway station. ${ }^{19}$ Of course, $20 \mathrm{~km}$ is an arbitrary cutoff: we have verified the robustness of the estimation results by taking different cutoff distances (see section 4).

18 We discarded the option to interact a time trend and seasonality with market pairs since this nearly exhausts the degrees of freedom in estimation. Moreover, we do have empirical support for trends and seasonality in prices (which explains part of the trend and seasonality is price dispersion), but trends and seasonality in prices dispersion are less evident from the data.

19 Practically this implies we have ten markets connected by rail (and thereby 45 intervention market pairs). These markets are: Bangula, Lilongwe, Limbe, Liwonde, Lizulu, Luchenza, Lunzu, Mchinji, Ntaja, and Salima (see also fig. 1; supplementary online appendix for a list with markets, distance-to-station, and latitude-longitude coordinates). 


\section{Estimations and Discussion}

\section{Other Empirical Issues}

In running the estimations, we have assumed that the impact of railway services is geographically restricted. Transport costs increase more or less proportionally with transport distance (and are, in this respect, different from search costs). As a result, the impact of availability of transport services is spatially restricted: transport costs are high and become prohibitive for markets that are a long distance away. As transport costs translate into higher prices of traded goods, there is a clear trade-off between "import" and local supply: local production or the use of close local substitutes could be cheaper alternatives than "import" from faraway locations, especially if there is no advantage from specialization and if the agricultural product could be produced anywhere. Therefore, we assume that (potential) domestic trade only takes place between markets that are located a limited distance away from each other.

How far this distance is needs to be investigated empirically. Aggregate data on freight by rail indicate that the average distance of freight by rail in the case of local freight is $80-115 \mathrm{~km}$, and in the case of export or import freight is $180-220 \mathrm{~km}$ (calculations based on aggregate CEAR data). For domestic passengers, the average distance traveled varies from 40 to $80 \mathrm{~km}$. Survey data on domestic trade and domestic traders, generally using (pickup) trucks as mode of transport, indicate that average distance between location of purchase and sale location of maize transactions is around $55 \mathrm{~km}$, with a maximum of $200 \mathrm{~km}$ (Fafchamps, Gabre-Madhin, and Minten 2005).

The distance over which crops are traded is likely to be influenced by perishability and storability of crops, whether the crop is a high- or low-value crop, the geographical spread of production and consumption, and how large expected gains from trade are. Because high-value crops have relatively lower transport costs, these crops are likely to be traded over longer distances. Next, trade in perishable crops is, by nature, spatially restricted: these crops simply degenerate if transported over long distances and thereby become unsellable (we ignore the possibility of cooled transport, which is not feasible for a typical Sub-Saharan African farmer-trader). Conversely, storable crops are more suitable to be traded over longer distances. Trade over longer distances may arise if production areas are more remote from consumption locations. Finally, the larger the gains, the larger the distance over which crops are traded. These expected gains from trade depend on the difference in prices in each location, which in turn depends on differences in the supply and demand balance across locations. ${ }^{20}$ A shortfall of local production relative to local demand will potentially give rise to high prices and is typical for urban areas. Seasonality in production will also lead to seasonality in prices, which will be more pronounced if demand is higher. Hence, differences in seasonality of prices across locations will affect expected gains from trade.

Moreover, we have also assumed that the period without railway services between the market pairs connected by rail is restricted. With the disruption of the railway bridge at Rivirivi, Balaka, a period started without railway services for markets along the railway line. The start of this period is 100 percent accurate. However, it is not clear when this period ended. From personal communication with CEAR staff we know that the railway bridge at Rivirivi was repaired and rail transport operations were resumed in May 2005. However, in the course of time the lack of railway services will lead to adjustments like the use of alternative modes of transport, increased local cultivation of food, and shifts in consumption to local substitutes. The speed of adjustment will depend on the availability of cheap alternative modes of transport, supply response of local production, and the resilience of demand to shift to other food. These adjustments are likely to have taken place, as domestic trade did not recover after rail transport operations were resumed (see fig. 2 and appendix A1 figs. A1.2 and A1.3). The CEAR operational strategy favoring international freight may also have played a role.

20 Availability of information on prices in several markets is obviously a key determinant of trade flows. Several studies highlight the importance of search costs and the availability of price information. 
On the basis of data on passenger and freight transport by rail, we have assumed in the estimations that the period in which the railway is effectively not operational is at least two years and at most three years. The minimum of two years is further motivated by the limited availability of price data around 2003 (see appendix A1 fig. A1.2). The maximum of three years is motivated by the fading out of the impact and is determined empirically, using a grid procedure (see supplementary online appendix).

\section{Selecting Maximum Trading Distance and Sample Period}

In the estimations we first employ a basic specification that is uniform across crops with respect to maximum trading distance $(100 \mathrm{~km})$, sample period (48 months before and 36 months after collapse), and cutoff distance to rail $(20 \mathrm{~km})$. All estimations include season-market dummies, a time trend for each market, month dummies, and market-pair dummies. Higher-order lags of the dependent variable are included if statistically significant at acceptable levels of significance. This strategy made us include a number of lagged dependent variables, which varied by crop. In all estimations the coefficients of lagged dependent variables are positive, decreasing in size with the order of the lag, and statistically significant. Estimations with a specification that is uniform across crops are fine for maize but are not convincing for other crops (see supplementary online appendix). We need to relax the assumption of a uniform maximum trading distance and sample period/period before and after bridge collapse to allow for heterogeneity between crops. We determine appropriate values of the maximum trading distance and the relevant period before and after the date of the collapse empirically, using a simple grid procedure: we estimate with a maximum trading distance varying from $70 \mathrm{~km}$ to $300 \mathrm{~km}$ (with a $10 \mathrm{~km}$ step), and with 24 to 48 months before and 24 to 36 months after January 2003. We use this procedure in order to find, simultaneously, the appropriate maximum trading distance and relevant period but also to assess the robustness of the estimations. Selected output of this exercise is reported in the supplementary online appendix.

On the basis of the tables and the underlying estimations reported in the supplementary online appendix, we observe for all four commodities sets of estimations with statistically significant average treatment effects (ATEs) with the expected negative sign around a specific combination of maximum trading distance and sample period. The regularity of these estimation outcomes-both across commodities and for each individual commodity across combinations-offers comfort in and credibility of the estimations. For all commodities we see impacts disintegrate if the period without railway services is extended to the year 2006 (not shown, available from the author on request): apparently the period effectively without railway services (i.e., the period with effectively higher dispersion of agricultural market prices) is limited to the years 2003, 2004, and 2005, which is consistent with the fact that railway services resumed operations in May 2005. In fact, this motivated us to include estimations that exactly matched this period (January 2003 to April 2005), which further improved estimations in the case of beans, groundnuts, and especially maize. Also, with a maximum trading distance of $70 \mathrm{~km}$ or less, and with only two full years of observations before and after the bridge collapse (January 2003), the estimations tend to generate spurious outcomes. Next, the impact in the case of rice becomes significant with a maximum trading distance of $140-180 \mathrm{~km}$ and for groundnuts with a maximum trading distance of $200-300 \mathrm{~km}$, opposed to around $100 \mathrm{~km}$ for maize and beans. The larger trading distance is possibly the result of the uneven spread of rice cultivation compared to the other commodities. Also, good storability (of rice and groundnuts) will make trade over longer distances easier.

The impact coefficients of all commodities with the exception of beans are around -11 percent, while in the case of beans the impact tends to be slightly stronger (see supplementary online appendix). We assume that this should be associated with the higher perishability of beans and the related reduced scope for intertemporal arbitrage (relative to storable commodities). Other studies also confirm a higher impact in case of perishable crops (see, for example, Jensen 2007; Muto and Yamano 2009; Aker and Fafchamps 2014). 
Table 1 shows a selection of the estimation results that allow for different maximum trading distances and sample periods across commodities and summarizes the key results of this study. The estimations confirm a statistically significant reduction in the dispersion of agricultural commodity prices across markets of around 9-12 percent. The size of the reduction is remarkably similar across commodities. The inclusion of the lagged dependent variable allows the distinction of short- and long-run impact, where the long-run impact is calculated as $\beta_{2} /\left(1-\sum_{i} \beta_{1 i}\right)$, using the notation from the regression model. Long-run impacts range from a reduction of 14 percent to a reduction of 17 percent. These results point at substantial welfare effects from the enhanced efficiency of markets for agricultural commodities. The reduction in price dispersion is also likely to affect growth because lower food prices in subsistence economies constitute an important transmission mechanism to higher productivity (see De Janvry and Sadoulet 2010).

Table 1. Impact of Rail Transport Services on Price Dispersion: Selected Output

\begin{tabular}{|c|c|c|c|c|}
\hline $\begin{array}{l}\text { Dependent variable: } \ln \left(\mathrm{abs}\left(\mathrm{p}_{\mathrm{jt}}-\mathrm{p}_{\mathrm{kt}}\right)\right) \\
\text { Crop / Commodity }\end{array}$ & (1) & (2) & (3) & (4) \\
\hline Crop / Commodity & Maize & Rice & Groundnuts & \\
\hline Connected by rail & $\begin{array}{c}-0.119 * * * \\
(0.0395)\end{array}$ & $\begin{array}{c}-0.109 * * * \\
(0.0416)\end{array}$ & $\begin{array}{l}-0.094 * * \\
(0.0374)\end{array}$ & $\begin{aligned} &-0.116 * * * \\
&(0.0346)\end{aligned}$ \\
\hline Lagged dependent variable $(t-1)$ & $\begin{array}{l}0.183 * * * \\
(0.0329)\end{array}$ & $\begin{array}{l}0.182 * * * \\
(0.0236)\end{array}$ & $\begin{array}{l}0.245^{* * *} \\
(0.0210)\end{array}$ & $\begin{array}{l}0.193 * * * \\
(0.0552)\end{array}$ \\
\hline Lagged dependent variable $(t-2)$ & & $\begin{array}{l}0.096 * * * \\
(0.0214)\end{array}$ & $\begin{array}{l}0.056 * * * \\
(0.0223)\end{array}$ & $\begin{array}{l}0.095 * * \\
(0.0441)\end{array}$ \\
\hline Lagged dependent variable $(t-3)$ & & & $\begin{array}{l}0.053 * * \\
(0.0262)\end{array}$ & \\
\hline Season $\mathrm{x}$ market dummies & yes & yes & yes & yes \\
\hline Time trend $\mathrm{x}$ market dummies & yes & yes & yes & yes \\
\hline Market-pair dummies & yes & yes & yes & yes \\
\hline Month dummies & yes & yes & yes & yes \\
\hline Covariates & no & no & no & no \\
\hline$R^{2}$ & 0.3898 & 0.4234 & 0.4202 & 0.4863 \\
\hline Max trading distance $(\mathrm{km})$ & 110 & 160 & 250 & 110 \\
\hline Sample period & $1 / 99-4 / 05$ & $1 / 99-4 / 05$ & $1 / 99-4 / 05$ & $1 / 00-4 / 05$ \\
\hline Months before $1 / 03$ and after $12 / 02$ & $48 ; 28$ & $48 ; 28$ & $48 ; 28$ & $36 ; 28$ \\
\hline Number of observations & 2062 & 2748 & 2930 & 1534 \\
\hline Number of intervention pairs & 251 & 366 & 365 & 157 \\
\hline Number of control pairs connected by rail & 161 & 190 & 210 & 107 \\
\hline Number of other controls (not connected) & 1650 & 2192 & 2355 & 1270 \\
\hline Long-term impact & -0.146 & -0.150 & -0.146 & -0.164 \\
\hline
\end{tabular}

Source: Authors' calculations based on data from AgroEconomic Survey, Ministry of Agriculture and Food Security, Malawi.

Note: The dependent variable: $\ln \left(\mathrm{abs}\left(\mathrm{p}_{\mathrm{jt}}-\mathrm{p}_{\mathrm{kt}}\right)\right)$ is the natural logarithm of the price difference between locations $j$ and $k$ in month $t$. Connected by rail has the value $\ln$ (distance) if both markets are less than $20 \mathrm{~km}$ away from a railway station while the railway was operational, and zero elsewhere (in the case of groundnuts, less than $10 \mathrm{~km}$ ). Prices are deflated with the rural consumer price index. Robust standard errors in parentheses below the coefficient are clustered by market pairs. The long-term effect is calculated as $\beta_{2} /\left(1-\sum_{i} \beta_{1 i}\right)$ (see regression model above). Estimation results with two-way clustered standard errors (by markets of each market pair) are shown in the supplementary online appendix. ${ }^{*} p<0.10, * * p<0.05,{ }^{* * *} p<0.01$

\section{Robustness of Estimation Results}

A number of robustness checks are implemented. We have repeated the estimations of table 1 with inclusion of covariates, notably (relative) per capita gross income, (the sum of market pairs) population density, and (relative) rainfall. Estimated impacts, reported in table 2, come close to the ones reported in table 1. Apparently the covariates are either independent of the intervention variable or well captured by the set of fixed effects applied in the basic estimations (or both). 
Table 2. Impact of Rail Transport Services on Price Dispersion: Including Covariates

\begin{tabular}{|c|c|c|c|c|}
\hline Dependent variable: $\ln \left(a b s\left(\mathrm{p}_{\mathrm{jt}}-\mathrm{p}_{\mathrm{kt}}\right)\right)$ & (1) & $(2)$ & (3) & (4) \\
\hline Crop / Commodity & Maize & Rice & Groundnuts & Beans \\
\hline Connected by rail & $\begin{array}{c}-0.111 * * \\
(0.0422)\end{array}$ & $\begin{array}{c}-0.124 * * * \\
(0.0408)\end{array}$ & $\begin{array}{c}-0.088 * * \\
(0.0372)\end{array}$ & $\begin{array}{c}-0.097 * * * \\
(0.0342)\end{array}$ \\
\hline Lagged dependent variable $(t-1)$ & $\begin{array}{c}0.159 * * * \\
(0.0304)\end{array}$ & $\begin{array}{c}0.189 * * * \\
(0.0238)\end{array}$ & $\begin{array}{c}0.244 * * * \\
(0.0219)\end{array}$ & $\begin{array}{c}0.171 * * * \\
(0.0637)\end{array}$ \\
\hline Lagged dependent variable $(t-2)$ & & $\begin{array}{c}0.090 * * \\
(0.0229)\end{array}$ & $\begin{array}{c}0.062 * * * \\
(0.0231)\end{array}$ & $\begin{array}{c}0.090 * \\
(0.0342)\end{array}$ \\
\hline Lagged dependent variable $(t-3)$ & & & $\begin{array}{c}0.053 * \\
(0.0273)\end{array}$ & \\
\hline Season $\mathrm{x}$ market dummies & yes & yes & yes & yes \\
\hline Time trend $\mathrm{x}$ market dummies & yes & yes & yes & yes \\
\hline Market-pair dummies & yes & yes & yes & yes \\
\hline Month dummies & yes & yes & yes & yes \\
\hline Covariates & yes & yes & yes & yes \\
\hline$R^{2}$ & 0.4098 & 0.4301 & 0.4246 & 0.5026 \\
\hline Max trading distance $(\mathrm{km})$ & 110 & 160 & 250 & 110 \\
\hline Sample period & $1 / 99-4 / 05$ & $1 / 99-4 / 05$ & $1 / 99-4 / 05$ & $1 / 00-4 / 05$ \\
\hline Months before $1 / 03$ and after $12 / 02$ & $48 ; 28$ & $48 ; 28$ & $48 ; 28$ & $36 ; 28$ \\
\hline Number of observations & 1834 & 2554 & 2801 & 1364 \\
\hline No. of intervention pairs & 212 & 317 & 335 & 127 \\
\hline No. of control pairs connected by rail & 139 & 172 & 196 & 84 \\
\hline No. of other controls (not connected) & 1483 & 2065 & 2270 & 1153 \\
\hline Long-term impact & -0.132 & -0.172 & -0.137 & -0.132 \\
\hline
\end{tabular}

Source: Authors' calculations based on data from AgroEconomic Survey, Ministry of Agriculture and Food Security, Malawi.

Note: The dependent variable: $\ln \left(\mathrm{abs}\left(\mathrm{p}_{\mathrm{jt}}-\mathrm{p}_{\mathrm{kt}}\right)\right)$ is the natural logarithm of the price difference between locations $\mathrm{j}$ and $\mathrm{k}$ in month $\mathrm{t}$. Connected by rail has the value $\ln$ (distance) if both markets are less than $20 \mathrm{~km}$ away from a railway station while the railway was operational, and zero elsewhere (in the case of groundnuts, less than $10 \mathrm{~km}$ ). Prices are deflated with the rural consumer price index. Robust standard errors in parentheses below the coefficient are clustered by market pairs. The long-term effect is calculated as $\beta_{2} /\left(1-\sum_{i} \beta_{1 i}\right)$ (see regression model above). Estimation results with two-way clustered standard errors (by markets of each market pair) are shown in the supplementary online appendix. ${ }^{*} p<0.10,{ }^{* *} p<0.05, * * * 0.01$

Measured impact may be the result of already existing differences in markets not related to the railway line as the railway track was not randomly placed. Hence, we need to show that variables develop along a common trend and have similar means and distributions outside the intervention period. Table 3 shows tests on the common trend assumption, outside the intervention period (January 2003 to April 2005). The tests suggest that we cannot reject the hypothesis of a common trend in all cases, with the exception of groundnuts.

Table 3. Common Trends in Price Dispersion Outside the Intervention Period

Differences in trends

\begin{tabular}{lll} 
Market-pair data & F-statistic (n,m) & $p$-value \\
\hline Maize price: $\ln \left|\mathrm{p}_{\mathrm{j}}-\mathrm{p}_{\mathrm{k}}\right|$ & $\mathrm{F}(2,67): 0.52$ & 0.599 \\
Rice price: $\ln \left|\mathrm{p}_{\mathrm{j}}-\mathrm{p}_{\mathrm{k}}\right|$ & $\mathrm{F}(2,103): 0.16$ & 0.856 \\
Groundnuts price: $\ln \left|\mathrm{p}_{\mathrm{j}}-\mathrm{p}_{\mathrm{k}}\right|$ & $\mathrm{F}(2,180): 5.11$ & $0.007 * * *$ \\
Beans price: $\ln \left|\mathrm{p}_{\mathrm{j}}-\mathrm{p}_{\mathrm{k}}\right|$ & $\mathrm{F}(2,67): 0.82$ & 0.444 \\
\hline Maize price: $\left|\mathrm{p}_{\mathrm{j}}-\mathrm{p}_{\mathrm{k}}\right|$ & $\mathrm{F}(2,67): 2.32$ & 0.106 \\
Rice price: $\left|\mathrm{p}_{\mathrm{j}}-\mathrm{p}_{\mathrm{k}}\right|$ & $\mathrm{F}(2,103): 0.25$ & 0.776 \\
Groundnuts price: $\left|\mathrm{p}_{\mathrm{j}}-\mathrm{p}_{\mathrm{k}}\right|$ & $\mathrm{F}(2,180): 9.02$ & $0.000^{* * *}$ \\
Beans price: $\left|\mathrm{p}_{\mathrm{j}}-\mathrm{p}_{\mathrm{k}}\right|$ & $\mathrm{F}(2,67): 1.09$ & 0.341 \\
\hline
\end{tabular}

Source: Authors' calculations based on data from AgroEconomic Survey, Ministry of Agriculture and Food Security, Malawi.

Note: $* p<0.10, * p<0.05, * * p<0.01$ 
Tests on means and distribution of intervention and non-intervention market pairs, outside the intervention period (see appendix A1 table A1.1), reveal a mixed picture: some means tests are indeterminate. Many variables at the level of both markets and market pairs, however, have different means and distributions. This should not be surprising. Markets are in different locations with different populations, different endowments, and different climates. In fact, we need differences between markets to generate trade. In summary, the test outcomes reported in table 3 and in appendix A1 do not invalidate the impact estimations especially as long as we adequately condition the variation in price dispersion on relevant covariates.

Next, we have run the estimations with two subsets of controls as a robustness check. One may argue that using remote market pairs as controls is merely measuring the difference between remote market pairs and market pairs along the rail line. Therefore, we have re-estimated impact by comparing market pairs (both) connected by rail with market pairs of which one market is located along the rail line (connected by rail) and the other market is not. Market pairs near the rail line but not connected are more likely to be similar to market pairs that are both connected to the rail line. In this way, we avoid comparing remote, isolated, and exclusively rural market pairs with exclusively urban market pairs, market pairs that are both located in a relatively densely populated area.

Conversely, one may argue that market pairs of which only one market is connected with the rail line are to some extent also benefiting from rail connection. Because this will blur the result, estimation with non-connected market pairs as controls should be preferred. Therefore, we have re-estimated impact by comparing market pairs (both) connected by rail with market pairs of which both markets are not connected by rail. The results (see appendix A1 tables A1.2 and A1.3) are different but to a large extent confirm previous results: coefficients of the impact variable and lagged dependent variables have the right sign, and statistical significance is acceptable to good in most estimations. The assertion that impacts reflect a selective choice of control market pairs is not supported by these robustness checks.

As a final robustness check, we have rerun the estimations with a smaller/larger number of intervention locations (see previous section). As a starting point, we have used $20 \mathrm{~km}$ as the cutoff to define locations to be intervention locations. Alternatively, we used a cutoff of less than $10 \mathrm{~km}$, leading to eight intervention locations and 28 intervention market pairs, and less than $30 \mathrm{~km}$, leading to 13 intervention locations and 78 intervention market pairs. The outcome of this exercise (not shown) indicates that the estimated impact remains more or less the same with a smaller number of intervention points but deteriorates substantially with a larger number of intervention points.

\section{Alternative Explanations and Potential Threats}

One may question the estimated impact of transport services by rail on agricultural commodity prices on several grounds. We consider three concerns in some detail. The first concern is about the bias caused by large cities. One may argue that the estimated impact is exclusively due to trade with the two main cities, Lilongwe and Blantyre. In terms of population these cities are much larger than all other cities and towns (Lilongwe and Blantyre are similar in population size, and five to six times larger than the third largest city, Mzuzu). Consequently, proportionally more trade will take place toward these cities and results may be driven by these cities. Omitting observations to a certain degree confirms this, because the results deteriorate (not shown). However, we do not consider this a major problem since domestic trade in food is naturally directed from excess-supply rural areas towards high demand urban markets.

The second concern is about substitutability between rail and road transport. Since road transport is possibly a close substitute to rail transport, measured impacts are possibly distorted, caused by other circumstances than the collapse of rail transport or not by the collapse of rail transport alone. If this is the case, impact is erroneously attributed to rail services or to rail services alone. With about $15,451 \mathrm{~km}$ of roads, of which 45 percent are paved, the road network is vastly larger than the railroad network $(797 \mathrm{~km}$; for a map of the road network, see appendix A1 fig. A1.1). Road infrastructure is clearly the 
dominant mode of transportation and readily and widely available. We claim, however, that substitutability between rail transport services and road transport services is unlikely to be high for domestic trade in agricultural products in view of transport costs, indivisibilities, and type of services supplied.

In Sub-Saharan Africa, per ton kilometer costs of transport are on average 40 to 210 percent higher for road transport than for rail transport. Since these are averages calculated for major African corridors rather than for secondary roads, and since the Malawi road transport market is far from competitive and characterized by inefficiencies and high costs (see Lall, Wang, and Munthali 2009), these differences between road and rail transport costs are presumably an underestimate of the true differences between rail and road transport in Malawi. High costs of road transport services make profitable trade opportunities for smallholder farmers' sales of agricultural produce in high-demand urban markets unlikely. Also, the quantity of output needed to fill up a pickup truck and the (non-)availability of backhaul cargo could create additional constraints that increase per kg costs of road transport. Conversely, rail transport services are available at lower per unit cost and on more flexible conditions in terms of quantities transported. For large groups of smallholder farmers and petty traders, rail transport is therefore the only option to realize income from trade in agricultural commodities. Costs of road transport are simply prohibitive. Consequently, substitutability between road and rail transport for this group will be close to negligible.

The third and final concern is the assumption that the bridge collapse has affected the operationality of the entire rail network. While this is indeed a strong assumption, we argue that this is a reasonable assumption in view of the available evidence and also due to the response of the railway operator (CEAR). The bridge collapse certainly affected the link between the two big cities, Lilongwe and Blantyre, and also the link between Nacala (Mozambique) and Lilongwe. The total collapse of tobacco freight by rail-primarily sourced from central and northern Malawi-from 2003 onward corroborates this assertion. Nevertheless, the link between Blantyre, the commercial capital of Malawi, to the ports of Nacala and Beira remained unaffected by the collapse of the bridge. This is especially important since it allowed Malawi to maintain essential levels of highly needed imports (fuel and fertilizer) and exports (sugar and tobacco exports, yielding foreign exchange to finance imports). In fact, despite a modest drop in import and export freight by rail since 2003, substantial levels of export and import freight were maintained jointly with a complete wipe-out of domestic freight (see supplementary online appendix). Apparently whatever capacity, operational rail infrastructure, and personnel was available after the bridge collapse was used for imports and exports. The railway operator has deliberately prioritized high-return import and export activities. Import and export freight only concerns a few mainly non-food products: trade in these products will not affect prices of agricultural commodities in local domestic markets. In this context the key trade channel that affects supply and demand of agricultural commodities in local markets is domestic freight and passenger services: these transport services directly influence the opportunities for trade in agricultural commodities by smallholder farmers and petty traders. As already mentioned, jointly with the sustained levels of exports and imports we observe a complete drop of domestic freight since 2003 (see appendix A1 figs. A1.2 and A1.3). Also, passenger services appear to have decreased since 2003. The evidence suggests that the rail operator has deliberately stepped down its activities in domestic trade and passenger services in view of the setbacks and in an attempt to improve commercial viability of its operations. Officially, passenger services are claimed to have been suspended after the bridge collapse for lack of subsidy from the Malawi government. Hence, impact of rail transport services on local markets of agricultural commodities through these channels was largely blocked.

\section{Summary and Conclusion}

In this study, we have measured the impact of railway services on the dispersion of market prices of agricultural commodities in Malawi. For this purpose, we have exploited the quasi-experimental design of the nearly total collapse of domestic transport by rail in January 2003 due to the destruction of a railway bridge 
at Rivirivi, Balaka. Estimations are based on monthly market prices of four agricultural commodities (maize, groundnuts, rice, and beans), in 27 local markets, for the period 1998-2006. The measured impact varies from a reduction in price dispersion of 9.5 to 12 percent in the short run to 14 and 17 percent in the long run, when railway transport is possible. Perishable and low-value crops (respectively beans and maize) tend to be traded over smaller distances and storable high-value crops over larger distances (rice and groundnuts). There is some support for a relatively larger impact on perishable commodities (beans), reflecting the limited scope for intertemporal arbitrage. Results depend critically on the maximum distance between market pairs, the period included before and after the collapse, and which markets are assumed to be connected by rail. Estimations are robust for including covariates and various subsets of control groups.

\section{References}

Ahlfeldt, G.M., S.J. Redding, D.M. Sturm, and N. Wolf. 2014. "The Economics of Density: Evidence from the Berlin Wall.” NBER Working Paper No. 20354, National Bureau of Economic Research, Cambridge, MA.

Aker, J. C. 2010. "Information for Markets Near and Far: Mobile Phones and Agricultural Markets in Niger." American Economic Journal: Applied Economics 2 (3): 46-59.

Aker, J. C., and M. Fafchamps. 2014. "Mobile Phone Coverage and Producer Markets: Evidence from West Africa." World Bank Economic Review 29 (2): 262-92.

Allen, T., and D. Atkin. 2015. "Volatility, Insurance, and the Gains from Trade.” NBER Working Paper No. 22276, National Bureau of Economic Research, Cambridge, MA.

Atkin, D., and D. Donaldson. 2012. "Who's Getting Globalized? The Size and Implications of Intranational Trade Costs." NBER Working Paper No. 21439, National Bureau of Economic Research, Cambridge, MA.

Bleakley, H., and J. Lin. 2012. "Portage and Path Dependence." Quarterly Journal of Economics 127 (2): 587-644.

Burgess, R., and D. Donaldson. 2012. "Railroads and the Demise of Famine in Colonial India." Working Paper, London School of Economics and Political Science, London.

Casaburi, L., R. Glennerster, and T. Suri. 2013. "Rural Roads and Intermediated Trade: Regression Discontinuity Evidence from Sierra Leone.” Working Paper, Department for International Development, London.

De Janvry, A., and E. Sadoulet. 2010. "Agriculture for Development in Africa: Business as Usual or New Departures.” Journal of African Economies 19 (Suppl 2): ii7-39.

Donaldson, D. 2010. "Railroads of the Raj: Estimating the Impact of Transportation Infrastructure." Working Paper No. 41, London School of Economics and Political Science, London (also forthcoming in American Economic Review).

Fafchamps, M., E. Gabre-Madhin, and B. Minten. 2005. "Increasing Returns and Market Efficiency in Agricultural Trade." Journal of Development Economics 78 (2): 406-42.

Fafchamps, M., and B. Minten. 2012. "Impact of SMS-Based Agricultural Information on Indian Farmers." World Bank Economic Review 27 (3): 1-32.

Fafchamps, M., and R. Vargas-Hill. 2005. "Selling at the Farmgate or Travelling to the Market." American Journal of Agricultural Economics 87 (3): 717-34.

Feyrer, J. 2009. "Distance, Trade, and Income-The 1967 to 1975 Closing of the Suez Canal as a Natural Experiment.” NBER Working Paper No. 15557, National Bureau of Economic Research, Cambridge, MA.

Goyal, A. 2010. "Information, Direct Access to Farmers and Rural Market Performance in Central India." American Economic Journal: Applied Economics 2 (3): 22-45.

Jacoby, H. G. 2000. “Access to Markets and the Benefits of Rural Roads.” Economic Journal 110 (465): 713-37.

Jacoby, H. G., and B. Minten. 2008. "On Measuring the Benefits of Lower Transport Costs." Policy Research Working Paper No. 4484, World Bank, Washington, DC.

Jedwab, R., E. Kerby, and A. Moradi. 2014. "History, Path Dependence and Development: Evidence from Colonial Railroads, Settlers and Cities in Kenya.” Working Paper WPS/2014-04, Centre for the Study of African Economies, Oxford, UK.

Jedwab, R., and A. Moradi. 2016. "The Permanent Effects of Transportation Revolutions in Poor Countries: Evidence from Africa." Review of Economics and Statistics 98 (2): 268-284. 
Jensen, R. 2007. "The Digital Provide: Information (Technology), Market Performance, and Welfare in the South Indian Fisheries Sector." Quarterly Journal of Economics 72 (3): 879-924.

Kaminski, J., L. Christiaensen, and C.L. Gilbert. 2016. "Seasonality in Local Food Prices and Consumption: Evidence from Tanzania." Oxford Economic Papers 68 (3): 736-57.

Knapp, B. J., and H. Posner III. 2004. “A luta continua!” Railway Gazette International, 160 (6): 363. Accessed June 10, 2017. http://www.railwaygazette.com/news/.

Lall, S. V., H. Wang, and T. Munthali. 2009. "Explaining High Transport Costs Within Malawi, Bad Roads or Lack of Trucking Competition?” Policy Research Working Paper No. 5133, World Bank, Washington, DC.

Michaels, G. 2008. "The Effect of Trade on the Demand for Skill: Evidence from the Interstate Highway System." Review of Economics and Statistics 90 (4): 683-701.

Millennium Challenge Corporation. 2011. "Millennium Challenge Corporation: Malawi Compact Program Development 2011-2016. Project Concept Paper for the Transport Sector: Promoting Economic Growth and Poverty Reduction Through Addressing Transport Infrastructure Constraints in Malawi.” Millennium Challenge Account-Malawi Country Office Secretariat. Accessed September 2013. http://www.mca-m.gov.mw.

Minten, B., and S. Kyle. 1999. "The Effect of Distance and Road Quality on Food Collection, Marketing Margins, and Traders' Wages: Evidence from the Former Zaire.” Journal of Development Economics 60 (2): 467-95.

Muto, M., and T. Yamano. 2009. "The Impact of Mobile Phone Coverage Expansion on Market Participation: Panel Data Evidence from Uganda.” World Development 37 (12): 1887-96.

Mvinyo, M. "Malawi: Accounting for the Privatisation of Malawi Railways Ltd." Chronicle (Lilongwe), February 7 , 2006.

National Statistical Office, 2005, Integrated Household Survey 2005 (IHS-2), Zomba, Malawi.

Redding, S. J., and D. M. Sturm. 2008. "The Costs of Remoteness: Evidence from German Division and Reunification." American Economic Review 98 (5): 1766-97.

Teravaninthorn, S., and G. Raballand. 2008. "Transport Prices and Costs in Africa: A Review of the Main International Corridors." Africa Infrastructure Country Diagnostic Report No. 14, World Bank, Washington, DC.

Wikipedia. “Tropical Storm Delfina.” Accessed June 9, 2017. https://en.wikipedia.org/wiki/Tropical_Storm_Delfina. World Bank. 2006. Sub-Saharan Africa - Review of Selected Railway Concessions. Washington, DC: World Bank.

Yamauchi, F., M. Muto, S. Chowdurry, R. Dewina, and S. Sumaryanto. 2011. "Are Schooling and Roads Complementary? Evidence from Income Dynamics in Rural Indonesia.” World Development 39 (12): 2232-44.

Zant, W. 2012. "The Economics of Food Aid Under Subsistence Farming with an Application to Malawi." Food Policy 37 (1): 124-41.

- 2013. "How Is the Liberalization of Food Markets Progressing? Market Integration and Transaction Costs in Subsistence Economies." World Bank Economic Review 27 (1): 28-54.

. 2016. "How Does Market Access Affect Export Supply? The Case of Tobacco Marketing in Malawi." Discussion Paper 16-054/V, Tinbergen Institute, Amsterdam. 


\section{Appendix A1: Description of Data and Robustness Checks}

Figure A1.1. Malawi Road Network

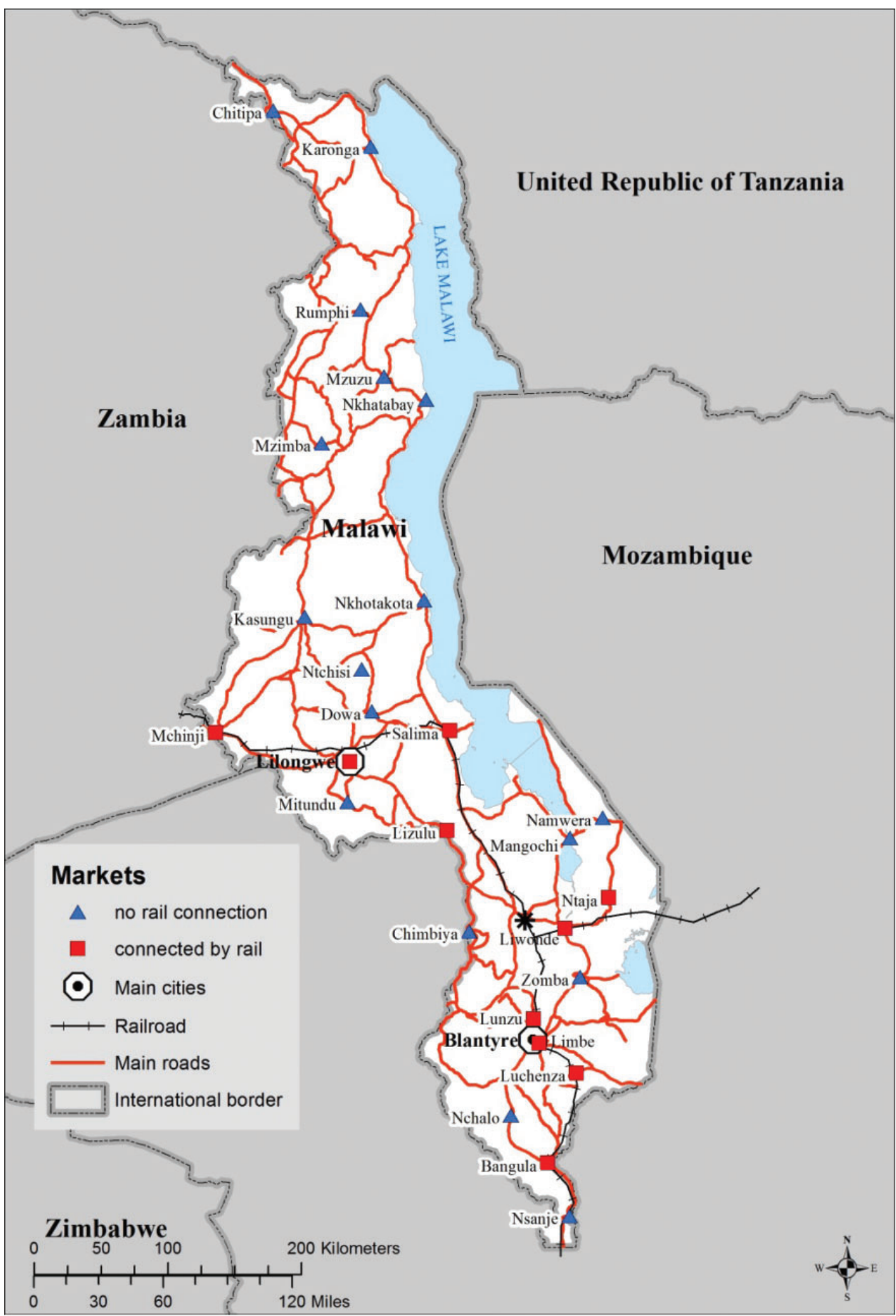


Figure A1.2. Domestic Trade by Rail (Annuals)

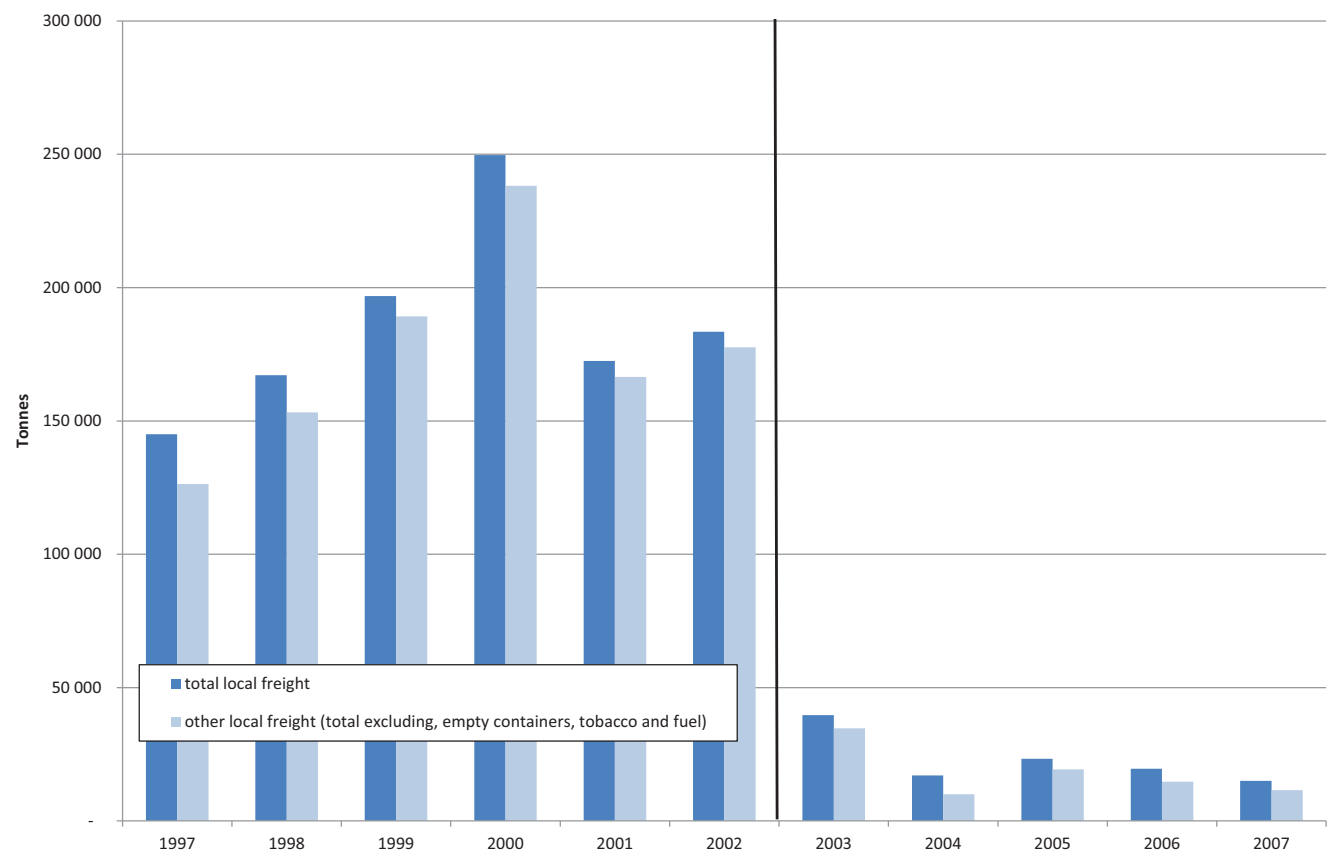

Source: Authors' calculations based on Central East African Railways data (CEAR).

Note: For the year 2004, we only have data on aggregate tonnage: composition is computed by interpolation.

Figure A1.3. Number of Domestic Rail Passengers (Annuals)

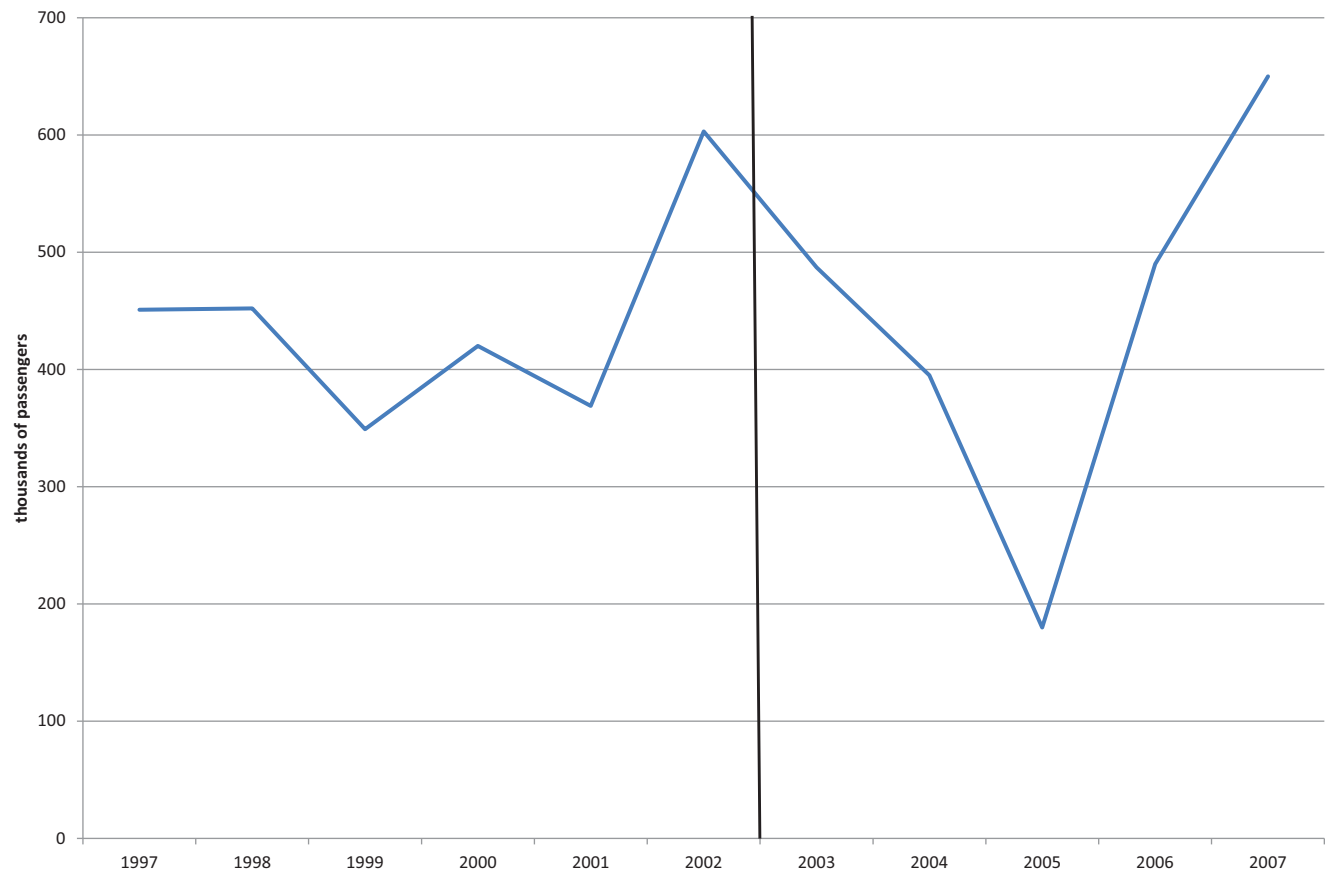

Source: Authors' calculations based on Central East African Railways data (CEAR). 
Table A1.1. Mean and Distribution of (Un)treated Observables Outside the Intervention Period

\begin{tabular}{|c|c|c|c|c|c|}
\hline & \multicolumn{2}{|c|}{ Unconditional mean (SE) } & \multirow{2}{*}{$\begin{array}{c}\text { Difference in means } \\
\text { F test ( } p \text {-value })\end{array}$} & \multicolumn{2}{|c|}{ Diff. in distributions } \\
\hline & Connected by rail & Not connected by rail & & D-statistic & $p$-value \\
\hline \multicolumn{6}{|l|}{ Market pair data } \\
\hline Maize price: $\left|\mathrm{p}_{\mathrm{j}}-\mathrm{p}_{\mathrm{k}}\right|$ & $4.10(0.25)$ & $4.34(0.23)$ & $\mathrm{F}(1,75): 0.51(0.48)$ & 0.047 & 0.80 \\
\hline Rice price: $\left|p_{j}-p_{k}\right|$ & $16.47(1.64)$ & $17.77(0.96)$ & $F(1,212): 0.47(0.50)$ & 0.052 & 0.41 \\
\hline Groundnuts price: $\left|\mathrm{p}_{\mathrm{j}}-\mathrm{p}_{\mathrm{k}}\right|$ & $41.70(5.96)$ & $45.80(1.98)$ & $F(1,103): 0.43(0.52)$ & 0.143 & $0.03 * *$ \\
\hline Beans price: $\left|p_{j}-p_{k}\right|$ & $34.67(3.32)$ & $36.71(1.89)$ & $F(1,75): 0.29(0.60)$ & 0.048 & 0.18 \\
\hline Distance: dist $_{\mathrm{jk}}$ & $4.57(0.10)$ & $4.55(0.05)$ & $F(1,121): 0.03(0.87)$ & 0.094 & $0.00 * * *$ \\
\hline Rainfall: $\left|\mathrm{rf}_{\mathrm{j}}-\mathrm{rf}_{\mathrm{k}}\right|$ & $0.18(0.02)$ & $0.19(0.01)$ & $F(1,121): 0.38(0.54)$ & 0.107 & $0.00 * * *$ \\
\hline Population density: & $10.71(0.16)$ & $10.18(0.08)$ & $\mathrm{F}(1,21): 8.97(0.00) * * *$ & 0.316 & $0.00 * * *$ \\
\hline Pc gross income: & $0.57(0.09)$ & $0.50(0.04)$ & $F(1,121): 0.55(0.46)$ & 0.189 & $0.00 * * *$ \\
\hline \multicolumn{6}{|l|}{ Market data } \\
\hline Maize price: $\mathrm{p}_{\mathrm{j}}$ & $3.18(0.02)$ & $3.15(0.03)$ & $F(1,26): 0.55(0.47)$ & 0.107 & 0.11 \\
\hline Rice price: $\mathrm{p}_{\mathrm{j}}$ & $4.51(0.04)$ & $4.56(0.03)$ & $\mathrm{F}(1,26): 1.19(0.29)$ & 0.104 & 0.13 \\
\hline Groundnuts price: $\mathrm{p}_{\mathrm{j}}$ & $4.87(0.07)$ & $4.84(0.05)$ & $F(1,26): 0.06(0.81)$ & 0.083 & 0.46 \\
\hline Beans price: $\mathrm{p}_{\mathrm{j}}$ & $4.80(0.05)$ & $4.75(0.06)$ & $F(1,26): 0.30(0.59)$ & 0.145 & $0.01 * *$ \\
\hline Rainfall: $\mathrm{rf}_{\mathrm{j}}$ & $-0.04(0.04)$ & $0.00(0.02)$ & $\mathrm{F}(1,26): 0.85(0.37)$ & 0.230 & $0.00 * * *$ \\
\hline Population density: $\mathrm{pd}_{\mathrm{j}}$ & $5.41(0.21)$ & $4.83(0.12)$ & $\mathrm{F}(1,26): 5.95(0.02)$ & 0.483 & $0.00 * * *$ \\
\hline pc gross income: $\mathrm{gi}_{\mathrm{j}}$ & $6.91(0.15)$ & $6.82(0.10)$ & $F(1,26): 0.29(0.60)$ & 0.191 & $0.00 * * *$ \\
\hline
\end{tabular}

Source: Authors' calculations based on data from AgroEconomic Survey, Ministry of Agriculture and Food Security, Malawi.

Note: Outside the intervention period is from January 2003 to April 2005. Market pairs "connected by rail" are market pairs where both markets are located within a distance of $20 \mathrm{~km}$ of a railway station. Market pairs "not connected by rail" are market pairs of which at least one market is located more than $20 \mathrm{~km}$ away from a railway station. The number of markets is 27 and hence the (potential) number of market pairs 351, but practically less due to imposing a maximum trading distance. Robust standard errors are clustered by market pairs or markets according to the type of data tested. Prices are deflated with the rural consumer price index (source: National Statistical Office, Zomba, Malawi). ${ }^{*} \mathrm{p}<0.10, * \mathrm{p}<0.05,{ }^{* * *} \mathrm{p}<0.01$.

Table A1.2. Testing robustness of the impact of rail transport services on price dispersion: Using Remote Market Pairs as a Control Group

\begin{tabular}{|c|c|c|c|c|}
\hline $\begin{array}{l}\text { Dependent variable: } \ln \left(\mathrm{abs}\left(\mathrm{p}_{\mathrm{jt}}-\mathrm{p}_{\mathrm{kt}}\right)\right) \\
\text { Crop / commodity }\end{array}$ & (1) & (2) & (3) & (4) \\
\hline Crop / commodity & Maize & Rice & & \\
\hline Connected by rail & $\begin{array}{c}-0.177 * * \\
(0.0817)\end{array}$ & $\begin{array}{c}-0.172 * * \\
(.0769)\end{array}$ & $\begin{array}{l}-0.151 * * \\
(0.0715)\end{array}$ & $\begin{array}{l}-0.189^{*} \\
(0.1110)\end{array}$ \\
\hline Lagged dependent variable $(t-1)$ & $\begin{array}{l}0.140 * * * \\
(0.0498)\end{array}$ & $\begin{array}{l}0.182 * * * \\
(0.0317)\end{array}$ & $\begin{array}{l}0.312 * * * \\
(0.0312)\end{array}$ & $\begin{array}{l}0.225^{* * *} \\
(0.0529)\end{array}$ \\
\hline Lagged dependent variable $(t-2)$ & & $\begin{array}{c}0.105 * * * \\
(0.0317)\end{array}$ & $\begin{array}{c}0.099 * * \\
(0.0715)\end{array}$ & \\
\hline Season $\mathrm{x}$ market dummies & yes & yes & yes & yes \\
\hline Time trend $\mathrm{x}$ market dummies & yes & yes & yes & yes \\
\hline Market-pair dummies & yes & yes & yes & yes \\
\hline Month dummies & yes & yes & yes & yes \\
\hline Covariates & no & no & no & no \\
\hline$R^{2}$ & 0.5038 & 0.4803 & 0.5194 & 0.6405 \\
\hline Max trading distance $(\mathrm{km})$ & 110 & 180 & 200 & 110 \\
\hline Sample period & $1 / 99-4 / 05$ & $1 / 99-4 / 05$ & $1 / 99-4 / 05$ & $1 / 00-4 / 05$ \\
\hline Months before $1 / 03$ and after $12 / 02$ & $48 ; 28$ & $48 ; 28$ & $48 ; 28$ & $36 ; 28$ \\
\hline Number of observations & 998 & 1635 & 1559 & 846 \\
\hline No. of intervention pairs & 251 & 502 & 422 & 178 \\
\hline No. of control pairs connected by rail & 161 & 235 & 219 & 135 \\
\hline No. of other controls (not connected) & 586 & 898 & 918 & 533 \\
\hline Long-term impact & -0.206 & -0.242 & -0.257 & -0.244 \\
\hline
\end{tabular}

Source: Authors' calculations based on data from AgroEconomic Survey, Ministry of Agriculture and Food Security, Malawi.

Note: See table 1, main text. ${ }^{*} \mathrm{p}<0.10, *{ }^{*} \mathrm{p}<0.05, * * \mathrm{p}<0.01$. 
Table A1.3. Testing robustness of the impact of rail transport services on price dispersion: Using Nearby Market Pairs as a Control Group

\begin{tabular}{|c|c|c|c|c|}
\hline Dependent variable: $\ln \left(\mathrm{abs}\left(\mathrm{p}_{\mathrm{jt}}-\mathrm{p}_{\mathrm{kt}}\right)\right)$ & (1) & $(2)$ & (3) & (4) \\
\hline Crop / Commodity & Maize & Rice & Groundnuts & Beans \\
\hline \multirow[t]{2}{*}{ Connected by rail } & $-0.130 * *$ & $-0.174 * * *$ & $-0.109^{*}$ & $-0.203 *$ \\
\hline & $(0.0572)$ & $(0.0649)$ & $(0.0581)$ & $(0.0846)$ \\
\hline \multirow[t]{2}{*}{ Lagged dependent variable $(t-1)$} & $0.170 * * *$ & $0.194 * * *$ & $0.265^{* * *}$ & $0.178 * *$ \\
\hline & $(0.0519)$ & $(0.0278)$ & $(0.0255)$ & $(0.0743)$ \\
\hline \multirow[t]{2}{*}{ Lagged dependent variable $(t-2)$} & & $0.087^{* * *}$ & $0.056 * *$ & $0.120 * *$ \\
\hline & & $(0.0279)$ & $(0.0276)$ & $(0.0578)$ \\
\hline Season $\mathrm{x}$ market dummies & yes & yes & yes & yes \\
\hline Time trend $\mathrm{x}$ market dummies & yes & yes & yes & yes \\
\hline Market-pair dummies & yes & yes & yes & yes \\
\hline Month dummies & yes & yes & yes & yes \\
\hline Covariates & no & no & no & no \\
\hline$R^{2}$ & 0.4675 & 0.4572 & 0.4111 & 0.4903 \\
\hline Max trading distance $(\mathrm{km})$ & 90 & 140 & 225 & 110 \\
\hline Sample period & $1 / 99-4 / 05$ & $1 / 99-4 / 05$ & $1 / 99-4 / 05$ & $1 / 00-4 / 05$ \\
\hline Months before $1 / 03$ and after $12 / 02$ & $48 ; 28$ & $48 ; 28$ & $48 ; 28$ & $36 ; 28$ \\
\hline Number of observations & 1036 & 1859 & 2225 & 1058 \\
\hline No. of intervention pairs & 175 & 342 & 451 & 128 \\
\hline No. of control pairs connected by rail & 110 & 178 & 241 & 97 \\
\hline No. of other controls (not connected) & 751 & 1339 & 1533 & 833 \\
\hline Long-term impact & -0.157 & -0.243 & -0.160 & -0.290 \\
\hline
\end{tabular}

Source: Authors' calculations based on data from AgroEconomic Survey, Ministry of Agriculture and Food Security, Malawi. Note: See table 1, main text. ${ }^{*} \mathrm{p}<0.10, * * \mathrm{p}<0.05, * * \mathrm{p}<0.01$. 